\title{
Signal transduction induced in Trypanosoma cruzi metacyclic trypomastigotes during the invasion of mammalian cells
}

\section{N. Yoshida ${ }^{1}$, \\ S. Favoreto Jr. ${ }^{1}$, \\ A.T. Ferreira ${ }^{2}$ and \\ P.M. Manque ${ }^{1}$}

\author{
Departamentos de 1 M icrobiologia, Imunologia e Parasitologia, and \\ 2Biofísica, Escola Paulista de Medicina, Universidade Federal de São Paulo, \\ São Paulo, SP, Brasil
}

\section{Correspondence \\ N. Yoshida \\ Departamento de Microbiologia, \\ Imunologia e Parasitologia \\ EPM, UNIFESP \\ R. Botucatu, 862,60 andar \\ 04023-062 São Paulo, SP \\ Brasil \\ Fax: +55-11-571-1095 \\ E-mail: nyoshida.dmip@epm.br}

Research supported by FAPESP (No. 94/3496-4). P.M. Manque and S. Favoreto Jr. were recipients of CAPES fellowships.

Received August 3, 1999 Accepted January 3, 2000

\section{Abstract}

Penetration of Trypanosoma cruzi into mammalian cells depends on the activation of the parasite's protein tyrosine kinase and on the increase in cytosolic $\mathrm{Ca}^{2+}$ concentration. We used metacyclic trypomastigotes, the T. cruzi developmental forms that initiate infection in mammalian hosts, to investigate the association of these two events and to identify the various components of the parasite signal transduction pathway involved in host cell invasion. We have found that i) both the protein tyrosine kinase activation, as measured by phosphorylation of a $175-\mathrm{kDa}$ protein ( $\mathrm{p} 175)$, and $\mathrm{Ca}^{2+}$ mobilization were induced in the metacyclic forms by the HeLa cell extract but not by the extract of T. cruzi-resistant K562 cells; ii) treatment of parasites with the tyrosine kinase inhibitor genistein blocked both p175 phosphorylation and the increase in cytosolic $\mathrm{Ca}^{2+}$ concentration; iii) the recombinant protein J18, which contains the full-length sequence of gp82, a metacyclic stage surface glycoprotein involved in target cell invasion, interfered with tyrosine kinase and $\mathrm{Ca}^{2+}$ responses, whereas the monoclonal antibody 3F6 directed at gp 82 induced parasite $\mathrm{p} 175$ phosphorylation and $\mathrm{Ca}^{2+}$ mobilization; iv) treatment of metacyclic forms with phospholipase $\mathrm{C}$ inhibitor $\mathrm{U} 73122$ blocked $\mathrm{Ca}^{2+}$ signaling and impaired the ability of the parasites to enter HeLa cells, and v) drugs such as heparin, a competitive $\mathrm{IP}_{3}$-receptor blocker, caffeine, which affects $\mathrm{Ca}^{2+}$ release from $\mathrm{IP}_{3}$-sensitive stores, in addition to thapsigargin, which depletes intracellular $\mathrm{Ca}^{2+}$ compartments and lithium ion, reduced the parasite infectivity. Taken together, these data suggest that protein tyrosine kinase, phospholipase $\mathrm{C}$ and $\mathrm{IP}_{3}$ are involved in the signaling cascade that is initiated on the parasite cell surface by gp 82 and leads to $\mathrm{Ca}^{2+}$ mobilization required for target cell invasion.

\section{Introduction}

To enter mammalian cells, the protozoan parasite Trypanosoma cruzi, the etiological agent of Chagas' disease in man, requires the activation of signal transduction pathways
Key words

- Trypanosoma cruzi

- Signal transduction

- Metacyclic trypomastigotes

- Protein kinase

- Calcium response

- Cell invasion both in the parasite and the host cell (1-7). In the process of cell invasion, the engagement of cell surface receptors is thought to trigger the signaling cascade that mobilizes various second messengers. Mobilization of one of such messengers, namely the calcium ion, 
promotes in the host cell the rearrangement of microfilaments (8), the recruitment of lysosomes to the site of T. cruzi entry (9) and parasite internalization (10). The flow of information from the cell surface to the intracellular components, leading to an increase in cytosolic free $\mathrm{Ca}^{2+}$ concentration, possibly occurs in the following manner. Binding of the infective trypomastigote forms to the target cell induces in the latter the activation of pertussis toxin-sensitive heterotrimeric $G$ protein (1). This, coupled to the activity of phospholipase $C$, generates inositol 1,4,5-triphosphate $\left(\mathrm{IP}_{3}\right)$ that participates in $\mathrm{Ca}^{2+}$ release from $\mathrm{IP}_{3}$-sensitive intracellular stores (8).

As to the signaling events in $T$. cruzi during mammalian cell invasion, the available data are still fragmentary. Upon contact with target cells, $\mathrm{Ca}^{2+}$ mobilization is triggered in trypomastigotes. This $\mathrm{Ca}^{2+}$ response, which is required for parasite penetration, is not elicited in noninfective epimastigote forms $(2,6)$. An early event in this cascade may include protein tyrosine kinase (PTK) activation, for treatment of trypomastigotes with PTK inhibitor genistein reduces cell invasion $(3,7)$. Whether PTK activation is associated with the $\mathrm{Ca}^{2+}$ response remains to be established.

In metacyclic trypomastigotes, the insectstage $T$. cruzi developmental forms that are infective to mammalian hosts, the interaction of the surface glycoprotein gp82 with an as yet to be defined host cell receptor appears to induce PTK activity (7). This molecule is also capable of inducing host cell $\mathrm{Ca}^{2+}$ mobilization (5) and has been implicated in the process of cell invasion (11). To advance our understanding on the metacyclic trypomastigote signal transduction pathway relevant for infection, experiments were performed i) to determine the possible association between PTK activation and $\mathrm{Ca}^{2+}$ response, ii) to examine the involvement of phospholipase $\mathrm{C}$ and $\mathrm{IP}_{3}$ in the parasite entry into target cells, and iii) to confirm the role of gp82 as the cell surface receptor that mediates signaling to the parasite interior.

\section{Material and Methods}

\section{T. cruzi, mammalian cells and cell invasion assay}

T. cruzi strain CL (12) was used throughout this study. Parasites were maintained by cyclic passage in mice and in axenic cultures. Liver infusion tryptose medium (13) and Grace's medium (Gibco, Gaithersburg, MD, USA) were used, respectively, to grow parasites and to obtain cultures enriched in metacyclic forms. Metacyclic trypomastigotes were purified by passage through a DEAE-cellulose column, as described (14). HeLa cells, the human carcinoma-derived epithelial cells, and human leukemic K562 cells (15) were grown at $37^{\circ} \mathrm{C}$ in Dulbecco's minimum essential medium (DMEM) supplemented with $10 \%$ fetal calf serum (FCS), streptomycin $(100 \mu \mathrm{g} / \mathrm{ml})$ and penicillin (100 $\mathrm{U} / \mathrm{ml}$ ) in a humidified $5 \% \mathrm{CO}_{2}$ atmosphere. Mammalian cell invasion assays were carried out as previously described (16) by seeding $10^{6}$ metacyclic forms onto each well of 24-well plates containing 13-mm diameter round glass coverslips coated with $2 \times 10^{5}$ HeLa cells. After 1-h incubation, the triplicate coverslips were washed in phosphatebuffered saline (PBS) and stained with Giemsa.

\section{Detection of tyrosine phosphorylated T. cruzi proteins}

In standard experiments, $5 \times 10^{7}$ parasites were incubated for $20 \mathrm{~min}$ at $37^{\circ} \mathrm{C}$ in the absence or presence of a mammalian cell extract, equivalent to $160 \mu \mathrm{g} / \mathrm{ml}$ protein, in a total volume of $200 \mu \mathrm{l}$. After washing with PBS, the parasites were disrupted at $4{ }^{\circ} \mathrm{C}$ in a lysis solution containing phosphatase and protease inhibitors $(50 \mathrm{mM}$ Tris- $\mathrm{HCl}, \mathrm{pH}$ 7.4, $150 \mathrm{mM} \mathrm{NaCl}, 1 \mathrm{mM}$ EDTA, $1 \%$ Triton 
$\mathrm{X}-100,1 \mathrm{mM} \mathrm{NaVO}$, $1 \mathrm{mM} \mathrm{NaF}, 1 \mathrm{mM}$ phenylmethylsulfonyl fluoride, $1 \mathrm{mM}$ iodoacetamide, $25 \mu \mathrm{g} / \mathrm{ml}$ leupeptin, and $25 \mu \mathrm{g} / \mathrm{ml}$ antipain). Lysates were dissolved in loading buffer and subjected to electrophoresis in a $10 \%$ SDS-polyacrylamide gel, under reducing conditions, and the proteins were transferred to a nitrocellulose membrane. Following blockage with PBS containing 5\% defatted milk, the nitrocellulose membrane was incubated with anti-phosphotyrosine antibodies (mouse monoclonal antibody from Sigma Chemical Co., St. Louis, MO, USA) diluted in PBS-milk for $1 \mathrm{~h}$ at room temperature. After several washes in PBS containing $0.05 \%$ Tween 20 , the membrane was incubated with peroxidase-conjugated antimouse IgG. The final reaction was developed by chemiluminescence using the ELC Western blotting detection reagent and Hyperfilm-MP from Amersham (Buckingham, UK).

\section{Preparation of mammalian cell extract}

The cell extract used in phosphorylation and $\mathrm{Ca}^{2+}$ signaling experiments was prepared as follows: after several washes in PBS, HeLa or K562 cells were sonicated on ice with an ultrasonic processor XL ( 2 pulses of $30 \mathrm{~s}$ each) in the presence of protease inhibitors (1 mM phenylmethylsulfonyl fluoride, $1 \mathrm{mM}$ iodoacetamide, $25 \mu \mathrm{g} / \mathrm{ml}$ leupeptin, and $25 \mu \mathrm{g} / \mathrm{ml}$ antipain). After ascertaining cell disruption under a phase contrast microscope, the sonicated preparation was centrifuged at $12,000 \mathrm{~g}$ for $5 \mathrm{~min}$ and the supernantant was collected and immediately used for experiments or stored at $-80^{\circ} \mathrm{C}$ until use.

\section{Determination of intracellular $\mathrm{Ca}^{2+}$ concentration}

To measure T. cruzi cytosolic free $\mathrm{Ca}^{2+}$, $\left[\mathrm{Ca}^{2+}\right]_{\mathrm{i}}$, parasites $\left(7 \times 10^{7}\right.$ cells $\left./ \mathrm{ml}\right)$ were washed in Tyrode solution $(137 \mathrm{mM} \mathrm{NaCl}$,
$2.7 \mathrm{mM} \mathrm{KCl}, 12 \mathrm{mM} \mathrm{NaHCO} 3,0.36 \mathrm{mM}$ $\mathrm{NaH}_{2} \mathrm{PO}_{4}, 0.53 \mathrm{mM} \mathrm{MgCl}_{2}, 1.36 \mathrm{mM} \mathrm{CaCl}_{2}$, and $5.5 \mathrm{mM}$ glucose) and incubated with fura-2/AM (Sigma) for $3 \mathrm{~h}$ at room temperature, and non-incorporated fura-2 was washed out. Fluorescence was read with a fluorophotometer SPEX AR-CM system (Spex Industries, Edison, NJ, USA) with dual wavelength excitation ( 340 and $380 \mathrm{~nm}$ ) and emission at $505 \mathrm{~nm}$. The increase in parasite $\left[\mathrm{Ca}^{2+}\right]_{\mathrm{i}}$ after the addition of a mammalian cell extract to $2.5 \mathrm{ml}$ of parasite suspension was calculated as described by Grynkiewicz et al. (17). For each preparation we determined $\mathrm{R}_{\max }$ and $\mathrm{R}_{\min }$, which correspond to the fluorescence ratio at 340 and $380 \mathrm{~nm}$ in the presence of saturating $\mathrm{Ca}^{2+}$ after treatment with $50 \mu \mathrm{M}$ digitonin, and in the absence of $\mathrm{Ca}^{2+}$, upon addition of $10 \mathrm{mM}$ ethylene glycol-bis(ß-aminoethyl ether) tetraacetic acid (EGTA), respectively. Some experiments were carried out with parasites in buffer $\mathrm{A}, \mathrm{pH} 7.2$, without $\mathrm{Ca}^{2+}$ and containing $116 \mathrm{mM} \mathrm{NaCl}, 5.4 \mathrm{mM} \mathrm{KCl}, 0.8 \mathrm{mM}$ $\mathrm{MgSO}_{4}, 5.5 \mathrm{mM}$ glucose, and $50 \mathrm{mM} \mathrm{N}-(2-$ hydroxyethyl)piperazine-N'-(2-ethanesulfonic acid) (HEPES).

\section{Purification of recombinant protein J18}

The recombinant protein J18 (18) containing the entire sequence of the metacyclic trypomastigote surface molecule gp 82 fused to glutathione S-transferase (GST) was purified from IPTG-induced Escherichia coli suspensions according to the procedure detailed in Ref. 19, followed by electroelution as described (20).

\section{Heparin loading by reverse permeabilization}

The method of Kobayashi et al. (21) was used, with slight modifications. Metacyclic trypomastigotes were incubated in the following sequence of solutions kept at $2^{\circ} \mathrm{C}$ : I) $20 \mathrm{~min}$ in $10 \mathrm{mM}$ EGTA, $120 \mathrm{mM} \mathrm{KCl}, 5$ $\mathrm{mM}$ ATP, $2 \mathrm{mM} \mathrm{MgCl}_{2}, 20 \mathrm{mM}$-tris 
(hydroxymethyl)methyl-2-aminoethanesulfonic acid (TES), $\mathrm{pH} 6.8$, at $2^{\circ} \mathrm{C}$; II) $90 \mathrm{~min}$ in $120 \mathrm{mM} \mathrm{KCl}, 5 \mathrm{mM} \mathrm{ATP}, 2 \mathrm{mM} \mathrm{MgCl}$, $20 \mathrm{mM}$ TES, pH 6.8 , at $2^{\circ} \mathrm{C}$; III) $30 \mathrm{~min}$ in $120 \mathrm{mM} \mathrm{KCl}, 5 \mathrm{mM}$ ATP, $10 \mathrm{mM} \mathrm{MgCl}_{2}, 20$ $\mathrm{mM}$ TES, pH 6.8 , at $2^{\circ} \mathrm{C}$; IV) $30 \mathrm{~min}$ in 140 $\mathrm{mM} \mathrm{NaCl}, 5 \mathrm{mM} \mathrm{KCl}, 10 \mathrm{mM} \mathrm{MgCl} 2,5.6$ $\mathrm{mM}$ glucose, $2 \mathrm{mM}$ MOPS, $\mathrm{pH} 7.1$, at $22^{\circ} \mathrm{C}$. To load heparin, $1 \mathrm{mg} / \mathrm{ml}$ heparin was added to the solutions used in steps I-IV. The parasites were warmed to $22-25^{\circ} \mathrm{C}$ and $\mathrm{CaCl}_{2}$ was added at 15 -min intervals to give the following concentrations: $0.001,0.01,0.1$ and $1.6 \mathrm{mM}$. After loading with heparin, parasite viability was ascertained by the ethidium bromide test (22). Control parasites were treated in the same manner except that heparin was not added.

\section{Treatment of parasites with different drugs}

Metacyclic trypomastigotes were treated with $1 \mu \mathrm{M}$ thapsigargin at $37^{\circ} \mathrm{C}$ for $30 \mathrm{~min}$. Control parasites were incubated under the same conditions in the presence of $0.1 \%$

Figure 1 - Phosphorylation of p175 and $\mathrm{Ca}^{2+}$ mobilization induced in T. cruzi metacyclic trypomastigotes. A, Parasites were incubated at $37^{\circ} \mathrm{C}$ for the indicated periods of time in the presence of HeLa cell or T. cruzi-resistant $\mathrm{K} 562$ cell extract, equivalent to $160 \mu \mathrm{g} / \mathrm{ml}$ protein. After washing in PBS, the parasites were lysed with detergent and the total lysates were subjected to SDS-PAGE and analyzed by immunoblotting using anti-phosphotyrosine antibodies. B, Sonicated extract of HeLa or K562 cells, containing an equivalent of $25 \mu \mathrm{g}$ protein, was added to fura2-loaded parasites at the indicated time (arrow) and $\left[\mathrm{Ca}^{2+}\right]$ was measured. Results representative of three experiments are presented.

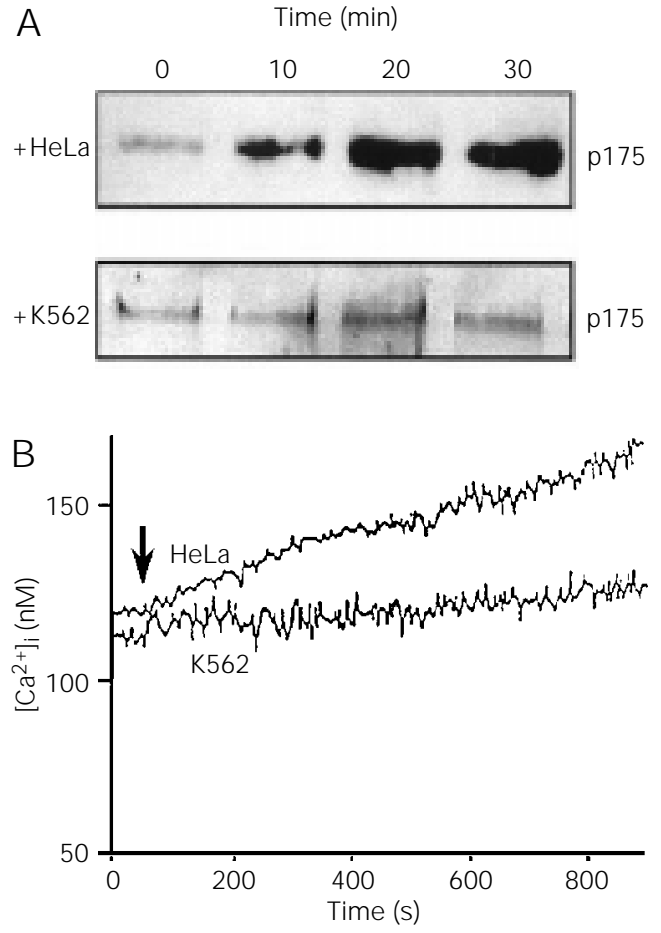

DMSO, equivalent to the DMSO concentration in the thapsigargin-treated samples. Caffeine treatment was performed by incubating the parasites at $37^{\circ} \mathrm{C}$ for $30 \mathrm{~min}$ with 10 $\mathrm{mM}$ of the drug. In both cases, the parasites were washed in buffer A before use. To inhibit phospholipase $\mathrm{C}$, the parasites were treated for $4 \mathrm{~min}$ at $37^{\circ} \mathrm{C}$ in the presence of $10 \mu \mathrm{M} \mathrm{U} 73122$, or were incubated with 100 $\mu \mathrm{M}$ neomycin for $4 \mathrm{~h}$ at $37^{\circ} \mathrm{C}$, washed in PBS and then used for the invasion assay. Parasites used as controls were incubated under the conditions described above in the absence of U73122 or neomycin.

\section{Results}

\section{Both p175 phosphorylation and $\mathrm{Ca}^{2+}$ mobilization are induced in metacyclic trypomastigotes by HeLa cells but not by the K562 cell extract}

We observed that the activation of $T$. cruzi PTK, as measured by the specific increase in the phosphorylation levels of a trypomastigote $175-\mathrm{kDa}$ protein ( $\mathrm{p} 175)$, is induced by exposure of parasites to cultured HeLa cells or to the sonicated extract. As the HeLa cell extract can be stored frozen without losing its phosphorylation-inducing activity, for practical reasons we have used the sonicated preparations in our study. The first assay to determine the association between PTK activation and $\mathrm{Ca}^{2+}$ response was carried out by i) incubating metacyclic trypomastigotes with HeLa cell or the K562 cell extract for varying periods of time, and then processing for immunoblot analysis using anti-phosphotyrosine antibodies, and ii) adding HeLa cell or K562 cell extract to fura-2loaded parasites and measuring the increase in $\left[\mathrm{Ca}^{2+}\right]_{i}$. As shown in Figure 1, the HeLa cell extract triggered an increase in the parasite cytosolic $\mathrm{Ca}^{2+}$ concentration in a manner compatible with the increase in the levels of p175 phosphorylation. By contrast, the extract of K562 cells, which are resistant to $T$. 
cruzi infection, did not show any PTK- or $\mathrm{Ca}^{2+}$ signal-inducing activity. The results were also negative when a two times more concentrated K562 cell extract was used.

Treatment of metacyclic trypomastigotes with genistein inhibits p175 phosphorylation and $\mathrm{Ca}^{2+}$ response

The next assay to determine the association between PTK activation and $\mathrm{Ca}^{2+}$ response was performed by i) incubating metacyclic trypomastigotes, untreated or treated with $250 \mu \mathrm{M}$ genistein for $30 \mathrm{~min}$ at $37^{\circ} \mathrm{C}$, in the absence or in the presence of HeLa cell extract for $20 \mathrm{~min}$ at $37^{\circ} \mathrm{C}$, and then processing for anti-phosphotyrosine immunoblotting, and ii) adding the HeLa cell extract to fura-2-loaded parasites, untreated or treated with genistein, and measuring $\left[\mathrm{Ca}^{2+}\right]_{i}$. Figure 2 shows that genistein, an inhibitor of protein tyrosine kinase (23) capable of inhibiting metacyclic trypomastigote entry into HeLa cells by $\sim 75 \%$ (7), blocked both the p175 tyrosine phosphorylation and $\mathrm{Ca}^{2+}$ mobilization, suggesting that the two events are associated.

\section{p175 phosphorylation and $\mathrm{Ca}^{2+}$ response in metacyclic forms are mediated by $9 p 82$}

To confirm the assumption that the metacyclic stage surface glycoprotein gp 82, which binds to HeLa cells in a receptor-dependent manner (11), plays a role in signal transduction, the following assay was performed. The PTK activation and $\mathrm{Ca}^{2+}$ response were determined upon incubation of parasites with HeLa cell extract in the absence or in the presence of $\mathrm{J} 18$, a recombinant protein containing the full-length gp82 sequence which binds to HeLa cells in the same manner as the native gp82 (19). In the PTK assay, the concentration of $\mathrm{J} 18$ in the reaction mixture was $250 \mu \mathrm{g} / \mathrm{ml}$. For $\left[\mathrm{Ca}^{2+}\right]_{\mathrm{i}}$ measurement, 50 $\mu \mathrm{l}$ of HeLa cell extract containing $250 \mu \mathrm{g} / \mathrm{ml}$ of $\mathrm{J} 18$ was added to fura-2-loaded parasites.
As shown in Figure 3, J18 inhibited both p175 phosphorylation- and $\mathrm{Ca}^{2+}$ signalinginducing activity of the HeLa cell extract. This result raises the possibility of isolating the signaling molecules from the HeLa cell extract using a gp82 affinity column. When metacyclic trypomastigotes were exposed to monoclonal antibody 3F6 directed at gp82,

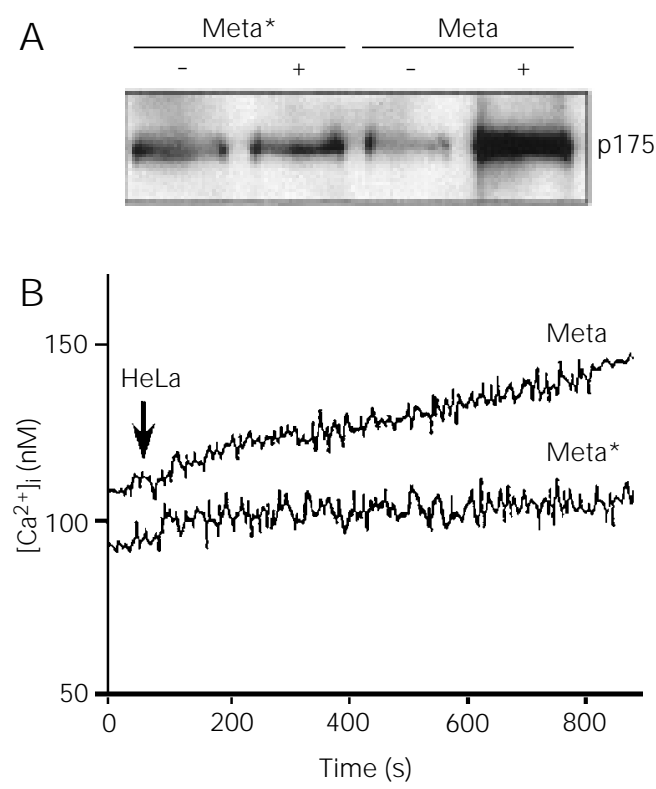

Figure 2 - Inhibition of T. cruzi metacyclic trypomastigote p175 phosphorylation and $\mathrm{Ca}^{2+}$ signaling by genistein. A, Metacyclic forms, untreated (Meta) or treated with $250 \mu \mathrm{M}$ of protein tyrosine kinase inhibitor genistein (Meta*), were incubated in the absence $(-)$ or in the presence $(+)$ of HeLa cell extract at $37^{\circ} \mathrm{C}$ for $20 \mathrm{~min}$, and then processed for anti-phosphotyrosine immunoblotting. B, HeLa cell extract was added at the indicated time (arrow) to fura-2loaded parasites, untreated (Meta) or treated with $250 \mu \mathrm{M}$ genistein (Meta*), and $\left[\mathrm{Ca}^{2+}\right]_{i}$ was measured. Results representative of three experiments are shown.
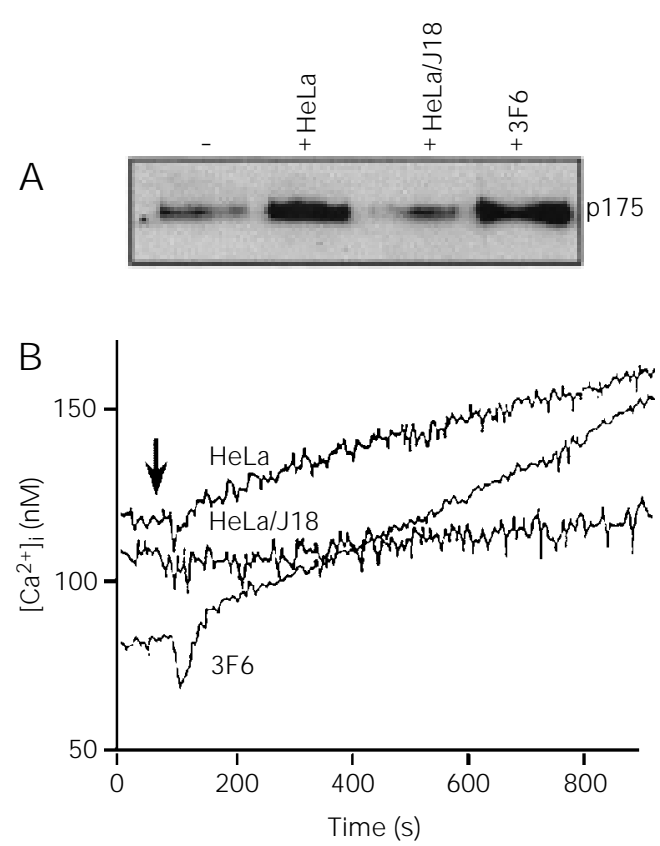

Figure 3 - Involvement of the T. cruzi metacyclic trypomastigote surface molecule gp82 with p175 tyrosine phosphorylation and $\mathrm{Ca}^{2+}$ response. A, Parasites were incubated in the absence $(-)$ or in the presence of HeLa cell extract, unmixed (+HeLa) or mixed with recombinant protein J 18 which contains the fulllength gp82 sequence (+HeLa/ $\mathrm{J} 18$ ), or were incubated with a monoclonal antibody directed at gp82 (+3F6). After $20 \mathrm{~min}$ at $37^{\circ} \mathrm{C}$, the parasites were processed for anti-phosphotyrosine immunoblotting. B, HeLa cell extract, mixed or not with J 18, or monoclonal antibody 3F6 was added at the indicated time (arrow) to fura-2-loaded metacyclic trypomastigotes and $\left[\mathrm{Ca}^{2+}\right]_{\mathrm{i}}$ was measured. 
Figure 4 - Effect of treatment of T. cruzi metacyclic trypomastigotes with thapsigargin or drugs that affect the $\mathrm{IP}_{3}$ signal on HeLa cell invasion. Parasites were: A, incubated at $37^{\circ} \mathrm{C}$ for $30 \mathrm{~min}$ in the absence or in the presence of $1 \mu \mathrm{M}$ thapsigargin; $\mathrm{B}$, treated or not for 30 min at $37^{\circ} \mathrm{C}$ with 10 $\mathrm{mM}$ caffeine; $\mathrm{C}$, loaded or not with $1 \mathrm{mg} / \mathrm{ml}$ heparin as described in the Methods section, or D, treated or not with $10 \mathrm{mM}$ $\mathrm{Li}^{+}$at room temperature for 45 min, and then seeded onto HeLa cells. After 1-h incubation at $37^{\circ} \mathrm{C}$, the number of intracellular parasites was counted in a total of 500 Giemsa-stained cells and the percentage of invasion determined. The values are means \pm SD of three independent assays.

Figure 5 - Inhibitory effect of thapsigargin and caffeine on $\mathrm{T}$. cruzi metacyclic trypomastigote $\mathrm{Ca}^{2+}$ mobilization. Monoclonal antibody $3 F 6$, directed at the metacyclic stage surface molecule gp82, was added at the indicated time (arrow) to fura-2loaded parasites, either untreated (c) or pretreated with thapsigargin (a) or caffeine (b) at $37^{\circ} \mathrm{C}$ for $30 \mathrm{~min}$, and $\left[\mathrm{Ca}^{2+}\right]_{i}$ was measured.

at $10 \mu \mathrm{g} / \mathrm{ml}$, both PTK activation and $\mathrm{Ca}^{2+}$ mobilization were triggered (Figure 3), supporting the idea of the involvement of gp82 in the signaling cascade.

\section{Metacyclic trypomastigote $\mathrm{Ca}^{2+}$ required for host cell invasion is released from intracellu- lar stores possibly in an $\mathbf{I P}_{\mathbf{3}}$-mediated manner}

In a series of experiments, we determined whether target cell invasion by metacyclic forms was dependent on $\mathrm{Ca}^{2+}$ released from the parasite intracellular compartments, more specifically from $\mathrm{IP}_{3}$-susceptible stores. First, the metacyclic forms either untreated or treated with thapsigargin, a sesquiterpene

A

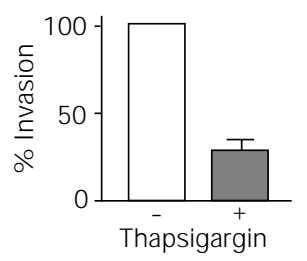

C
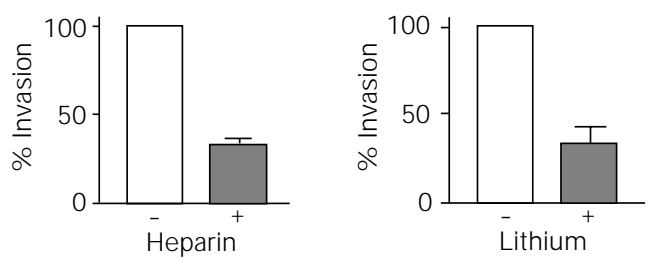

lactone that depletes intracellular $\mathrm{Ca}^{2+}$ stores in many mammalian cell types by specific inhibition of endoplasmic reticulum $\mathrm{Ca}^{2+}$ ATPase (24), were incubated with HeLa cells for $1 \mathrm{~h}$ at $37^{\circ} \mathrm{C}$ in DMEM containing $2 \%$ FCS. Following washes in PBS, HeLa cells were stained with Giemsa and the number of intracellular parasites was counted in a total of 500 cells. As shown in Figure 4A, thapsigargin-treated parasites entered $\mathrm{HeLa}$ cells in significantly lower numbers as compared to untreated controls. Consistent with this observation, $\mathrm{Ca}^{2+}$ mobilization was barely detectable in thapsigargin-treated parasites upon stimulation with monoclonal antibody 3F6, in contrast to untreated controls (Figure 5).

Next, we tested the effect of caffeine, which inhibits $\mathrm{IP}_{3}$-induced $\mathrm{Ca}^{2+}$ release in different cell types $(25,26)$. Caffeine-treated parasites and untreated controls were seeded onto HeLa cells and incubated as described above. The infectivity of caffeine-treated parasites was significantly decreased (Figure 4B) and this fact was correlated with a greatly reduced $\mathrm{Ca}^{2+}$ response (Figure 5). In another assay, we used parasites subjected to reversible permeabilization to incorporate heparin, a blocker of $\mathrm{IP}_{3}$-activated $\mathrm{Ca}^{2+}$ release in smooth muscle cells $(21,27)$, as described in the Methods section. After incubation with $\mathrm{HeLa}$ cells for $1 \mathrm{~h}$ at $37^{\circ} \mathrm{C}$ in DMEM- $2 \%$ FCS, the number of intracellular parasites was counted in 500 Giemsastained cells. As compared to controls, the heparin-loaded parasites displayed a reduced cell invasion rate (Figure 4C). We also determined whether the invasive capacity of $\mathrm{Li}^{+}-$ treated parasites was reduced. Lithium is assumed to block the recycling of $\mathrm{IP}_{3}$, but treatment with $\mathrm{Li}^{+}$may eventually result in loss of the $\mathrm{IP}_{3}$ signal. For instance, exposure of agonist-stimulated cerebral cortex slices or adrenal glomerulosa to $\mathrm{Li}^{+}$for longer than $5 \mathrm{~min}$ has been reported to suppress $\mathrm{IP}_{3}$ generation $(28,29)$. Metacyclic trypomastigotes treated with $10 \mathrm{mM} \mathrm{LiCl}$ for $45 \mathrm{~min}$ at 
room temperature before addition to HeLa cells were internalized in significantly lower numbers than the untreated controls (Figure 4D). The viability of the parasites was not affected by treatment with thapsigargin, caffeine, lithium or heparin loading. They retained their normal morphology and motility and were fully viable, as evaluated by Trypan blue staining and the ethidium bromide test.

\section{Phospholipase $\mathrm{C}$ inhibitor blocks $\mathrm{Ca}^{2+}$ response and reduces parasite infectivity}

$\mathrm{IP}_{3}$ is generated by phospholipase C-mediated hydrolysis of phosphatidylinositol 4,5biphosphate (30). As our results indicated the participation of $\mathrm{IP}_{3}$ in signal transduction required for cell invasion by metacyclic forms, we reasoned that inhibition of the parasite phospholipase $\mathrm{C}$ would affect its ability to enter host cells. To test that hypothesis, the parasites were treated with phospholipase C inhibitor U73122 (31) and then assayed for HeLa cell invasion. As shown in Figure 6A, U73122-treated parasites entered HeLa cells in significantly lower numbers than untreated controls. In addition to U73122, the effect of neomycin, another phospholipase $\mathrm{C}$ inhibitor (32), was examined. Although to a lesser extent than U73122, neomycin also inhibited the parasite infectivity (Figure 6B). Consistent with the inhibition of $\mathrm{IP}_{3}$-mediated $\mathrm{Ca}^{2+}$ release by the drug, no significant $\mathrm{Ca}^{2+}$ response was detected in U73122-treated parasites (Figure $6 \mathrm{C})$. However, we have noted a higher basal level of cytosolic $\mathrm{Ca}^{2+}$ concentration in U73122-treated parasites, suggesting also the possibility of a nonspecific effect of the drug in releasing $\mathrm{Ca}^{2+}$ from intracellular stores (33).

\section{The inhibitory effect of different drugs is reversible}

To test whether the effect of the various drugs was reversible, metacyclic trypomas- tigotes were treated with the drug, washed in PBS and then left to rest for $1 \mathrm{~h}$ at room temperature before seeding onto HeLa cells. Unlike the parasites used for the cell invasion assay immediately after drug treatment, the metacyclic forms incubated for $1 \mathrm{~h}$ in the absence of thapsigargin, caffeine, $\mathrm{Li}^{+}$or U73122 entered HeLa cells in numbers comparable to those of untreated controls, indicating the reversible effect of these compounds. The reversibility of heparin action was not determined, but its reversible antagonism of $\mathrm{IP}_{3}$-activated $\mathrm{Ca}^{2+}$ release has been demonstrated in other cell types (27).

\section{Discussion}

In the present study we analyzed the signal transduction events in $T$. cruzi metacyclic trypomastigotes required for mammalian cell invasion. Previous studies have shown the requirement of protein tyrosine kinase activation, that results in p175 phosphorylation, and the increase in cytosolic $\mathrm{Ca}^{2+}$ concentration (5-7). Our results indicate that $\mathrm{Ca}^{2+}$ mobilization in metacyclic
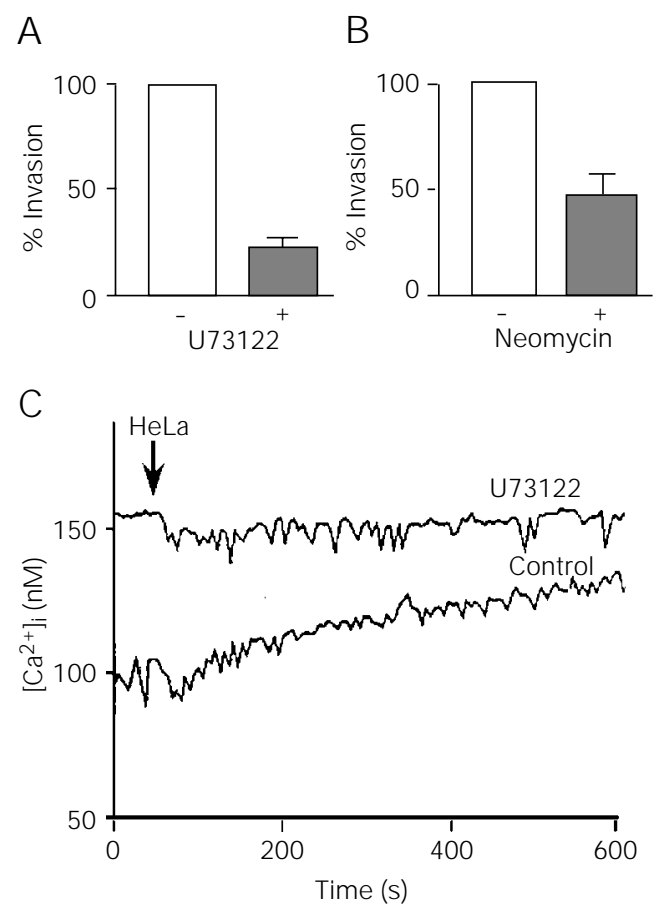

Figure 6 - Inhibition of HeLa cell invasion and $\mathrm{Ca}^{2+}$ response by treatment of $\mathrm{T}$. cruzi metacyclic trypomastigotes with phospholipase $C$ inhibitor. Parasites were treated or not with: A, $10 \mu \mathrm{M}$ U73122 for 4 min at $37^{\circ} \mathrm{C}$, and $\mathrm{B}, 100 \mu \mathrm{M}$ neomycin at $37^{\circ} \mathrm{C}$ for $4 \mathrm{~h}$ and then washed. Following incubation of parasites with HeLa cells at $37^{\circ} \mathrm{C}$ for $1 \mathrm{~h}$, percent invasion was determined by counting the number of intracellular parasites in a total of 500 Giemsa-stained cells. C, HeLa cell extract was added to fura-2loaded parasites, either untreated (control) or treated with $10 \mu \mathrm{M}$ U73122 for $4 \mathrm{~min}$ at $37^{\circ} \mathrm{C}$, and $\left[\mathrm{Ca}^{2+}\right]_{i}$ was measured. The values are means \pm SD of three assays. 
forms is dependent on PTK activation, so that the inhibition of the enzyme activity with the specific inhibitor genistein also inhibits the $\mathrm{Ca}^{2+}$ response (Figure 2).

The signaling cascade in metacyclic trypomastigotes is presumably initiated by recognition of the surface glycoprotein gp 82 by its target cell receptor. Thus, if this recognition is prevented, for instance by the presence of gp82 recombinant protein, PTK activation and $\mathrm{Ca}^{2+}$ response cannot be induced (Figure 3). On the other hand, binding of the monoclonal antibody 3F6 to gp82, possibly by mimicking the parasite ligand-host cell receptor interaction, triggers $\mathrm{p} 175$ phosphorylation and $\mathrm{Ca}^{2+}$ mobilization (Figure 3 ). The next event in the metacyclic stage signal transduction pathway, following engagement of gp82, is probably PTK activation. How gp82, which is anchored to the plasma membrane via the glycosylphosphatidylinositol (GPI) moiety (34), associates with tyrosine kinase is not known. In mammalian cells, at least two possibilities of association of GPIanchored surface molecules with tyrosine kinases have been reported. The neuron survival factor neurturin, for instance, was shown to signal through multicomplex receptors that consist of receptor tyrosine kinase and a member of a GPI-linked family of receptors that determine ligand specificity (35). Protein tyrosine kinases have been found in complexes immunoprecipitated from $T$ cells with antibodies directed at GPIlinked proteins $(36,37)$. Interaction of GPIanchored proteins and kinases could also be mediated by transmembrane linker proteins (38).

Activation of phospholipase $\mathrm{C}$, that leads to $\mathrm{IP}_{3}$ generation and $\mathrm{Ca}^{2+}$ mobilization, is possibly the next step in the metacyclic trypomastigote-signaling pathway. We have found that treatment of parasites with the phospholipase C inhibitor U73122 blocked the $\mathrm{Ca}^{2+}$ response and the ability to invade HeLa cells (Figure 6). Whether different phospholipase $\mathrm{C}$ isozymes are present in $T$. cruzi, and in this case which form is activated during target cell invasion, is one of the many questions that remain to be investigated. Also to be clarified is the mode of association of protein PTK or p175 with phospholipase C.

The increase in cytosolic $\mathrm{Ca}^{2+}$ necessary for metacyclic trypomastigote entry into host cells may originate from thapsigargin-sensitive intracellular $\mathrm{Ca}^{2+}$ stores in an $\mathrm{IP}_{3}$-mediated manner. First, treatment of parasites with thapsigargin, which depletes intracellular $\mathrm{Ca}^{2+}$ stores by inhibiting endoplasmic reticulum $\mathrm{Ca}^{2+}$-ATPase (24), significantly reduced both the $\mathrm{Ca}^{2+}$ response (Figure 5) and the ability to enter HeLa cells (Figure 4). Second, drugs that interfere with $\mathrm{IP}_{3}$-mediated $\mathrm{Ca}^{2+}$ release, such as heparin, caffeine and lithium, reduced the parasite infectivity (Figure 4). Although our data suggest that $\mathrm{IP}_{3}$-mediated $\mathrm{Ca}^{2+}$ release occurs in metacyclic trypomastigotes, this event has not been detected in studies with other T. cruzi developmental forms in spite of the presence of inositol phosphates $(39,40)$. The basis for such discrepancies has yet to be determined.

Although a number of questions still remain to be answered, taken together, our results suggest that interaction of the metacyclic trypomastigote surface molecule gp 82 with its host cell receptor triggers a signaling cascade leading to sequential activation of protein tyrosine kinase and phospholipase $\mathrm{C}$, with consequent generation of $\mathrm{IP}_{3}$ that promotes $\mathrm{Ca}^{2+}$ mobilization necessary for parasite internalization.

\section{Acknowledgments}

We thank Dr. Maria E. Oshiro for valuable suggestions. 


\section{References}

1. Tardieux I, Nathanson MH \& Andrews NW (1994). Role in host cell invasion of Trypanosoma cruzi-induced cytosolic free $\mathrm{Ca}^{2+}$ transients. J ournal of Experimental Medicine, 179: 1017-1022.

2. Moreno SNJ, Silva J, Vercesi AE \& Docampo R (1994). Cytosolic-free calcium elevation in Trypanosoma cruzi is required for cell invasion. J oumal of Experimental Medicine, 180: 1535-1540.

3. Vieira MCF, Carvalho TU \& Souza W (1994). Effect of protein kinase inhibitors on the invasion process of macrophages by Trypanosoma cruzi. Biochemical and Biophysical Research Communications, 203: 967-971.

4. Yakubu MA, Majumder $S \&$ Kierszenbaum $F$ (1994). Changes in Trypanosoma cruzi infectivity by treatments that affect calcium ion levels. Molecular and Biochemical Parasitology, 66: 119-125.

5. Dorta ML, Ferreira AT, Oshiro MEM \& Yoshida N (1995). $\mathrm{Ca}^{2+}$ signal induced by Trypanosoma cruzi metacyclic trypomastigote surface molecules implicated in mammalian cell invasion. Molecular and Biochemical Parasitology, 73: 285-289.

6. Ruiz RC, Favoreto S, Dorta ML, Oshiro MEM, Ferreira AT, Manque PM \& Yoshida N (1998). Infectivity of Trypanosoma cruzi strains is associated with differential expression of surface glycoproteins with differential $\mathrm{Ca}^{2+}$ signaling activity. Biochemical J ournal, 330: 505-511.

7. Favoreto S, Dorta ML \& Yoshida N (1998). Trypanosoma cruzi 175-kDa protein tyrosine phosphorylation is associated with host cell invasion. Experimental Parasitology, 89: 188-194.

8. Rodriguez A, Rioult MG, Ora A \& Andrews N (1995). A trypanosome-soluble factor induces $\mathrm{IP}_{3}$ formation, intracellular $\mathrm{Ca}^{2+}$ mobilization and microfilament rearrangement in host cells. J ournal of Cell Biology, 129: 1263-1273.

9. Tardieux I, Webster P, Ravesloot J , Boron W, Lunn JA, Huser JE \& Andrews NW (1992). Lysosome recruitment and fusion are early events required for Trypanosoma invasion of mammalian cells. Cell, 71 : 1117-1130.

10. Andrews NW (1995). Lysosome recruitment during host cell invasion by Trypanosoma cruzi. Trends in Biology, 5: 133137.

11. Ramirez MI, Ruiz RC, Araya J E, Franco da Silveira J \& Yoshida N (1993). Involvement of the stage-specific 82-kilodalton adhesion molecule of Trypanosoma cruzi metacyclic trypomastigotes in host cell invasion. Infection and Immunity, 61: 3636-3641.

12. Brener Z \& Chiari E (1963). Variações morfológicas observadas em diferentes amostras de Trypanosoma cruzi. Revista do Instituto de Medicina Tropical de São Paulo, 5: 220-224.

13. Camargo EP (1964). Growth and differentiation in Trypanosoma cruzi. I. Origin of metacyclic trypanosomes in liquid media. Revista do Instituto de Medicina Tropical de São Paulo, 6: 93-100.

14. Teixeira MMG \& Yoshida N (1986). Stagespecific surface antigens of metacyclic trypomastigotes of Trypanosoma cruzi identified by monoclonal antibodies. Molecular and Biochemical Parasitology, 18: 271282.

15. Lozzio CB \& Lozzio BB (1975). Human chronic myelogenous leukemia cell-line with positive Philadelphia chromosome. Blood, 45: 321-334.

16. Yoshida N, Mortara RA, Araguth MF, GonzalezJ \& Russo M (1989). Metacyclic neutralizing effect of monoclonal antibody 10D8 directed to the 35 and 50 kilodalton surface glycoconjugates of Trypanosoma cruzi. Infection and Immunity, 57: 16631667.

17. Grynkiewicz G, Poenie $M \&$ \& Tsien RY (1985). A new generation of $\mathrm{Ca}^{2+}$ indicators with greatly improved fluorescence. J ournal of Biological Chemistry, 260: 3440-3450.

18. Araya J E, Cano MI, Yoshida N \& Franco da Silveira J (1994). Cloning and characterization of a gene for the stage-specific 82 $\mathrm{kDa}$ surface antigen of metacyclic trypomastigotes of Trypanosoma cruzi. Molecular and Biochemical Parasitology, 65: 161-169.

19. Santori $F R$, Dorta $M L$, J uliano $L$, J uliano MA, Franco da Silveira J, Ruiz RC \& Yoshida N (1996). Identification of a domain of Trypanosoma cruzi metacyclic trypomastigote surface molecule gp62 required for attachment and invasion of mammalian cells. Molecular and Biochemical Parasitology, 78: 209-216.

20. Wheatley M (1993). Peptide mapping and the generation and isolation of sequentiable peptides from receptors. In: Hulme EC (Editor), Receptor Biochemistry. A Practical Approach. IRL Press at Oxford University Press, Oxford, UK, 213-261.

21. Kobayashi S, Kitazawa T, Somlyo AV \&
Somlyo AP (1989). Cytosolic heparin inhibits muscarinic and $\alpha$-adrenergic $\mathrm{Ca}^{2+}$ release in smooth muscle. J ournal of Biological Chemistry, 264: 17997-18004.

22. Vercesi $A E$, Hoffmann ME, Bernardes CF \& Docampo R (1991). Regulation of intracellular homeostasis in Trypanosoma cruzi. Effects of calmidazolium and trifluoperazine. Cell Calcium, 12: 361-369.

23. Akiyama T, Ishida J, Nakagawa S, Ogawara $\mathrm{H}$, Watanabe $\mathrm{S}$, Itoh $\mathrm{N}$, Shibuya M \& Fukami Y (1987). Genistein, a specific inhibitor of tyrosine-specific protein kinases. Journal of Biological Chemistry, 262: 5592-5595.

24. Thastrup O, Cullen PJ , Drobak BK, Hanley MR \& Dawson AP (1990). Thapsigargin, a tumor promoter, discharges intracellular $\mathrm{Ca}^{2+}$ stores by specific inhibition of the endoplasmic reticulum $\mathrm{Ca}^{2+}$-ATPase. Proceedings of the National Academy of Sciences, USA, 87: 2466-2470.

25. Brown GR, Sayers LG, Kirk CJ, Michell RH \& Michelangelli F (1992). The opening of the inositol 1,4,5-triphosphate-sensitive $\mathrm{Ca}^{2+}$ channel in rat cerebellum is inhibited by caffeine. Biochemical J ournal, 282: 309-312.

26. Hirose $K$, lino $M \&$ Endo $M$ (1993). Caffeine inhibits $\mathrm{Ca}^{2+}$-mediated potentiation of inositol 1,4,5-triphosphate-induced $\mathrm{Ca}^{2+}$ release in permeabilized vascular smooth muscle cells. Biochemical and Biophysical Research Communications, 194: 726-732.

27. Ghosh TK, Eis PS, Mullaney J M, Ebert CL \& Gill DL (1988). Competitive, reversible, and potent antagonism of inositol 1,4,5triphosphate-activated calcium release by heparin. J ournal of Biological Chemistry, 263: 11075-11079.

28. Balla $T$, Enyedi $P$, Hunyadi $L \&$ Spät $A$ (1984). Effect of lithium on angiotensinstimulated phosphatidylinositol turnover and aldosterone production in adrenal glomerulosa cells: a possible causal relationship. FEBS Letters, 171: 179-182.

29. Batty I \& Nahorski SR (1985). Differential effects of lithium on muscarinic receptor stimulation of inositol phosphates in rat cerebral cortex slices. J ournal of Neurochemistry, 45: 1514-1521.

30. Berridge MJ (1993). Inositol triphosphate and calcium signalling. Nature, 361: 315325.

31. Bleasdale JE, Thakur R, Gremban RS, Bundy GL, Fitzpatrick FA, Smith RJ \& Bunting S (1990). Selective inhibition of 
receptor-coupled phospholipase C-dependent processes in human platelets and polymorphonuclear neutrophils. J ournal of Pharmacology and Experimental Therapeutics, 255: 756-768.

32. Ma L \& Michel WC (1998). Drugs affecting phospholipase C-mediated signal transduction block the olfactory cyclic nucleotide-gated current of adult zebrafish. J ournal of Neurophysiology, 79: 1183-1192.

33. Taylor C \& Broad LM (1998). Pharmacological analysis of intracellular $\mathrm{Ca}^{2+}$ signalling: problems and pitfalls. Trends in Pharmacological Sciences, 19: 370-375.

34. Cardoso de Almeida MI \& Heise N (1993). Proteins anchored via glycosylphosphatidylinositol and solubilizing phospholipases in Trypanosoma cruzi. Biological Research, 26: 285-312.

35. Buj-Bello A, Adu J , Piñon LGP, Horton A, Thompson J , Rosenthal A, Chinchetru M, Buchman VL \& Davies AM (1997). Neurturin responsiveness requires a GPIlinked receptor and the ret receptor tyrosine kinase. Nature, 387: 721-724.

36. Stefanova I, Horejsi V, Ansotegui IJ, Knapp W \& Stockinger H (1991). GPI-anchored cell surface molecules complexed to protein tyrosine kinase. Science, 254: 1016-1019.

37. Thomas PM \& Samelson LE (1992). The glycosylphosphatidylinositol anchored Thy1 molecule interacts with the p60fyn protein tyrosine kinase in T cells. J ournal of Biological Chemistry, 276: 12317-12322.
38. Brown D (1993). The tyrosine kinase connection: how gpi-anchored proteins activate T cells. Current Opinion in Immunology, 5: 349-354.

39. Moreno SNJ , Vercesi AE, Pignataro OP \& Docampo R (1992). Calcium homeostasis in Trypanosoma cruzi amastigotes: presence of inositol phosphates and lack of inositol 1,4,5-triphosphate-sensitive calcium pool. Molecular and Biochemical Parasitology, 52: 251-262.

40. Docampo R, Moreno SNJ \& Vercesi AE (1993). Effect of thapsigargin on calcium homeostasis in Trypanosoma cruzi trypomastigotes and epimastigotes. Molecular and Biochemical Parasitology, 59: 305-314. 